Diabetologia 10, 45-52 (1974)

(C) by Springer-Verlag 1974

\title{
In Vivo Studies on Lipogenesis in Obese Hyperglycaemic (ob/ob) Mice: Possible Role of Hyperinsulinaemia*
}

\author{
E. G. Loten, A. Rabinovitch and B. Jeanrenaud \\ Laboratoires de Recherches Médicales, Division de Diabétologie et de Biochimie clinique, Département de Médecine, \\ Geneva University Medical School, Geneva, Switzerland
}

Received: July 30, 1973, and in revised form: October 1, 1973

Summary. C57BL/6J ob/ob mice are obese, hyperglycaemic and hyperinsulinaemic, and are relatively insensitive to the action of exogenously administered insulin. These animals convert more of an intravenous dose of radioactive glucose to lipids in both adipose tissue and liver than do control mice. The lipogenic capacities of the intestine, skin and remaining carcass however are not greatly different from those of lean mice. While lean mice respond to intravenous insulin with a marked increase in incorporation of labelled glucose into lipids in adipose tissue, obese mice do not.

Both lean and obese mice made diabetic with streptozotocin have a decreased plasma insulin and convert less glucose to fatty acids than do non-treated mice. This is particularly marked in the case of the adipose tissue of obese mice. Similarly, reduction of insulin levels by the injection of anti-insulin serum also caused a decreased lipogenesis which was particularly marked in the case of obese mice.

It is postulated that part of the increased lipogenesis seen in $o b / o b$ mice may be due to the abnormally high circulating insulin levels in these mice.

Key words: ob/ob mice, insulin, streptozotocin, antiinsulin serum, adipose tissue, liver, lipogenesis.
The C57BL/6J ob/ob mouse provides an interesting model of diabetes in that it presents, concomitantly, obesity, hyperglycaemia and hyperinsulinaemia, associated with resistance to the action of exogenously administered insulin. It has been reported that these mice have an increased capacity to incorporate radioactive precursors into lipids, in vivo, in the liver $[1,2$, $3,4]$, the carcass $[1,2]$ and adipose tissue [3]. One group [3], has reported an increased incorporation of orally administered radioactive glucose into liver lipids, but not into carcass lipids. There has, however, been no systematic study of the relative importance of tissues, other than liver and adipose tissue, to total lipogenesis in obese mice. This work was therefore undertaken in an attempt to measure the contribution of a variety of tissues to lipogenesis in the whole animal and to determine whether or not any increased lipogenesis observed was simply a response to the abnormally high insulin levels in obese mice.

Lipogenesis was investigated in normal and obese mice by intravenous administration of a standard small dose of ${ }^{14} \mathrm{C}$ glucose to the mice; the incorporation of radioactivity into lipid fractions in different tissues was measured after varying periods of time. To assess the role of insulin in influencing lipogenesis in the hyperinsulinaemic $o b / o b$ mice, a similar approach was used in mice made hypoinsulinaemic with streptozotocin or with anti-insulin serum.

* This work has been supported by Grant No. 3.552.71 of the Fonds National Suisse de la Recherche scientifique, Berne, Switzerland, and by a grant-in-aid of Zyma S.A., Nyon, Switzerland.

\section{Materials and Methods}

Animals used in this study were male $\mathrm{C} 57 \mathrm{BL} / 6 \mathrm{~J}$ $+1+$ lean mice and $\mathrm{C57 \textrm {BL } / 6 \mathrm { J }}$ ob/ob obese mice purchased from the Jackson Memorial Laboratories (Bar Harbor, Maine). They were kept in our animal room for at least one week before use and were fed ad-lib with "Altromin"-R mouse pellets. This diet contains $19 \%$ protein, $4 \%$ fat and $54 \%$ carbohydrate. Mice were used between the ages of 9 and 12 weeks. Fed mice were anaesthetised with an intraperitoneal injection of Nembutal $0.5 \mathrm{mg} / 10 \mathrm{gm}$ body weight. Five minutes later they received a further Nembutal injection $(0.1 \mathrm{mg} / 10 \mathrm{~g}$ body weight subcutaneously) and this was repeated, if necessary, during the experiment. Mice were left $15 \mathrm{~min}$ following the first subcutaneous injection of Nembutal before any experimental manipulations were begun. Throughout the experiment they were kept on a pad of cotton waste, beneath a lamp, to maintain their body temperature.

$\mathrm{U}_{-}{ }^{14} \mathrm{C}$ glucose $(5 \mu \mathrm{C} /$ mouse $3 \mathrm{mC} / \mathrm{m}$ mole in $0.1 \mathrm{ml}$ saline) was injected into a tail vein. At various times from 1 to $90 \mathrm{~min}$ after this, the animals were killed by exsanguination from the inferior vena cava, or from the heart, and the blood placed in heparinised tubes. The liver, and epididymal fat pads were then rapidly removed. The intestinal tract from the lower oesophagus to the upper rectum was separated along its mesenteric border and freed from as much fat as possible. A sample of subcutaneous adipose tissue was taken from each side of the animal, from the dorsal lumbar region, just above the pelvio girdle, and the entire skin was removed. The remaining carcass was 
also analysed. Immediately after removal, the tissues were weighed and homogenised in methanol. The liver and adipose tissue were finely chopped with scissors and then treated with ultrasound (Branson Sonic Power Co., Conn. U.S.A.) to complete the disintegration. The intestine, skin and carcass were homogenised in a Serval omnimixer (Ivan Sorval Inc. Conn. U.S.A.). Subsequently chloroform was added to the homogenate to extract lipids by the method of Folch et al. [5]. The extraction of lipids from the skin and carcass by this procedure was judged to be complete since re-extraction in chloroform-methanol two more times yielded essentially no more lipid. The final, washed, lower chloroform phase from the lipid extraction procedure was divided into two aliquots. One was evaporated to dryness, weighed, and then counted in $10 \mathrm{ml}$ of a toluene based scintillation mixture. The second aliquot was evaporated to dryness and then saponified for $1 \mathrm{~h}$ at $85^{\circ} \mathrm{C}$ in an excess of alcoholic KOH. After saponification $1 \mathrm{ml}$ of water was added and the non saponifiable lipids were extracted with two washes of $5 \mathrm{ml}$ each of light petroleum ether (B.P. $30-45^{\circ} \mathrm{C}$ ). The aqueous phase was then acidified and the fatty acids extracted with three $5 \mathrm{ml}$ washes of petroleum ether. The petroleum ether fractions were pooled, evaporated to dryness and counted in $10 \mathrm{ml}$ of scintillation mixture, yielding the radioactivity in non saponifiable lipids and in glyceride fatty acids respectively.

The plasma obtained from the animals was used to determine glucose using the glucose oxidase kit supplied by Boehringer (Mannheim, Germany), and to estimate the radioactivity in glucose using the procedure described by Exton and Park [6] for liver perfusates. The validity of the latter procedure in the present experimental circumstances was checked by using thin layer chromatography to separate the labelled glucose.

In some experiments an aliquot of the plasma was extracted by the method of Folch et al. [5], the extract washed, dried, saponified and the radioactivity in the fatty acid fraction determined. In other experiments an aliquot was used to determine immunoreactive insulin with the assay procedure described by Herbert et al., using rat insulin as a standard [7].

In several experiments it was desired to remove the liver from the circulation during an experiment in order to prevent hepatic lipid synthesis and subsequent transport of the newly synthesised lipids to other tissues. A modification of the procedure described by Russell [8] was used for this purpose. Ligatures were placed around the portal vein, close to the liver, and around the hepatic artery, thus preventing blood from reaching the organ.

When the mice were given insulin it was administered intravenously in three doses, the first along with the ${ }^{14} \mathrm{C}$-glucose and two further doses at $30 \mathrm{~min}$ intervals. Lean mice received $0.4 \mu / \mathrm{kg}$ in the first dose and $0.2 \mu / \mathrm{kg}$ in each of the subsequent injections. For obese mice the figures were $1.2 \mu / \mathrm{kg}$ for the first injection and
$0.6 \mu / \mathrm{kg}$ for the subsequent two injections. Streptozotocin treated mice received either $180 \mathrm{mg} / \mathrm{kg}$ or 200 $\mathrm{mg} / \mathrm{kg}$ intraperitoneally for lean mice or obese mice respectively. Mice were fasted $24 \mathrm{~h}$ before streptozotocin treatment and the drug was dissolved in saline acidified to $\mathrm{pH} 4.0$ with citric acid immediately before use. The urine of these animals was checked daily using "clinistix". The animals were used 8 days after treat. ment. The anti-insulin serum used was a gift from $\mathrm{Dr}$. P.H. Wright, Indianapolis, Indiana, and had an insulin neutralising capacity of $2 \mathrm{mU} / \mu \mathrm{l}$ against bovine insulin. Anaesthetised mice received $0.1 \mathrm{ml}$ of this preparation intravenously 30 min before the administration of ${ }^{14} \mathrm{C}$ glucose.

Pancreatic immunoreactive insulin content was determined after extracting the whole pancreas three times with acid ethanol [9], and measuring the insulin in the pooled extracts.

Radioactive counting was performed in a Packard Tri-Carb scintillation spectrometer (model 3380). The scintillation fluid used for counting lipid samples consisted of 2,5-diphenyloxazole $4 \mathrm{~g}$, and p-Bis 2-(5-phenyloxazolyl)-benzine $40 \mathrm{mg} / \mathrm{l}$ of toluene. Aqueous samples were counted in the same mixture modified to contain $300 \mathrm{ml}$ of ethanol per litre. All counts were corrected by the use of the automatic external standard, and this procedure was periodically checked by the use of internal standards.

\section{Calculations}

Expression of results is always a difficulty when comparing obese and lean animals and we have decided that the most meaningful way to do so is to make comparisons on a per animal basis. In the case of those experiments where each animal received the same trace dose of labelled glucose, the results then provide an indication of the amount of this precursor which is converted to lipid by each animal, lean or obese. Thus the values given for liver correspond to the entire liver. In the case of the skin and the carcass, both of which are contaminated to a variable extent with adipose tissue, this contribution of adipose tissue has been subtracted. The contribution of adipose tissue to the values obtained was estimated by multiplying the amount of lipid found in the tissue by the specific activity of adipose tissue in $\mathrm{dpm} / \mathrm{g}$ lipid. In the case of skin the specific activity of lipid from subcutaneous adipose tissue was used for the calculation, and in the case of the carcass a mean value of the specific activities of lipid from epididymal pads and samples of subcutaneous adipose tissue was used. The calculation described above utilised the amount of total lipid in the skin and carcass respectively and not, as would have been theoretically better, the triglyceride content. However the two values have been found to be very similar, especially in the case of the obese mice where the correction is quantitatively more important. It is clear that this method provides only an approximation, but in practice the errors are not large. Similarly a 
value for the total $\mathrm{dpm}$ found in adipose tissue is derived by multiplying the mean of the specific activities of lipid from epididymal fat pads and subcutaneous adipose tissue by the total lipid extracted from the animal. Again the errors in this procedure are not great. However, such calculations are only possible when the specific activities of lipid from the two types of adipose tissue are not significantly different. This is the case in normal mice in the basal state and in obese mice under all conditions. However, when lean mice are treated with insulin or with anti-insulin serum the specific activities of lipid extracted from the two adipose tissue sites are widely different. In this case the procedure could not be used and results are expressed simply as the specific activities of the extracted lipid.

The incorporation of radioactivity into glyceride glycerol was calculated from the difference between the counts in total lipids and the counts in nonsaponifiable lipids plus the saponifiable fatty acids.

\section{Materials}

Insulin used in these studies was monocomponent insulin obtained from Novo Laboratories, Copenhagen. The streptozotocin was a gift from Dr. Dulin of Upjohn, Kalamazoo, Michigan. Uniformly labelled ${ }^{14} \mathrm{C}$ glucose $3 \mathrm{mC} / \mathrm{m}$ mole was purchased from The Radiochemical Centre, Amersham, Buckinghamshire, U.K. All other chemicals were of analytical grade.

\section{Results}

In Table 1 are presented the weights, the body lipid contents, plasma insulin levels and pancreatic insulin contents of the two types of mice used in this the lower glucose specific radioactivity, the fractional removal rate of glucose calculated from these data is not different between the lean and the obese mice. However the absolute glucose disposal by obese mice is greater than that in the lean. The accumulation of radioactivity in saponifiable fatty acids of the liver and adipose tissue, following the intravenous injection of a trace of ${ }^{14} \mathrm{C}$ glucose is presented in Fig. 2. It is clear that the obese mice incorporate more label into lipids, in both the liver and adipose tissue, than do lean mice. It can also be seen that under these conditions the lean mice incorporate relatively little label into lipids. By contrast there was no significant difference in lipid

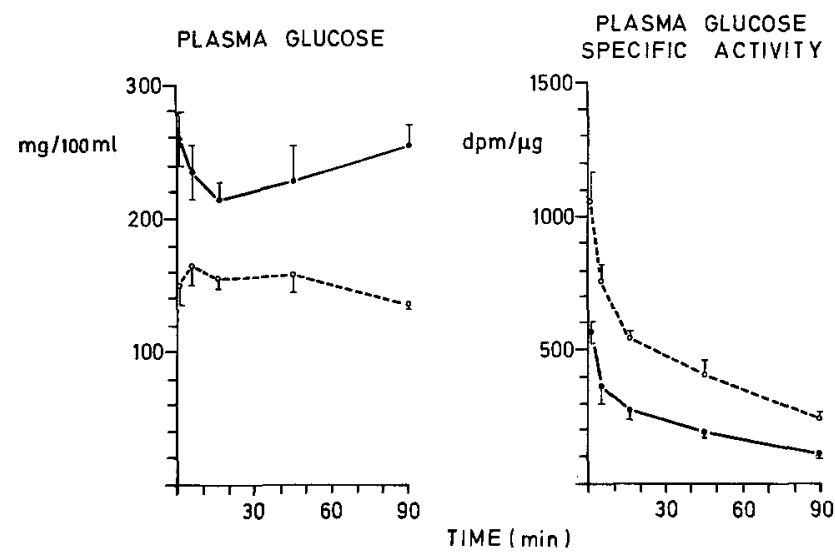

Fig. 1. Plasma glucose and glucose specific radioactivity in lean and $o b / o b$ mice following an intravenous dose of ${ }^{14} \mathrm{C}$ glucose. Anaesthetised mice were given $5 \mu \mathrm{C}$ of ${ }^{14} \mathrm{C}$ glucose into a tail vein and at various times later their plasma glucose measured and its specific radioactivity determined. Each value is the mean from 6 mice \pm SEM 0 -... lean mice - $a b / o b$ mice

Table 1. Body weight, body lipid content, plasma insulin and pancreatic insulin content of lean and ob/ob mice

\begin{tabular}{lllllll}
\hline & $\begin{array}{l}\text { Age in } \\
\text { weeks }\end{array}$ & $\begin{array}{l}\text { Weight } \\
\mathrm{g}\end{array}$ & $\begin{array}{l}\text { Total body } \\
\text { lipid } \\
\mathrm{g}\end{array}$ & $\begin{array}{l}\text { Percentage of } \\
\text { body weight } \\
\text { as lipid }\end{array}$ & $\begin{array}{l}\text { Plasma } \\
\text { IRI ng/ml }\end{array}$ & $\begin{array}{l}\text { Pancreatic } \\
\text { IRI content } \\
\text { ng/pancreas }\end{array}$ \\
\hline Lean & $9-12$ & $\begin{array}{l}25.3 \pm 0.8 \\
(25)\end{array}$ & $\begin{array}{l}2.7 \pm 0.1 \\
(25)\end{array}$ & 10.6 & $1.0 \pm 0.1$ & $8057 \pm 828$ \\
Obese & $9-12$ & $\begin{array}{l}42.3 \pm 1.0 \\
(25)\end{array}$ & $\begin{array}{l}20.8 \pm 0.7 \\
(25)\end{array}$ & 49.2 & $\begin{array}{l}(10) \\
18.3 \pm 5.9\end{array}$ & $\begin{array}{l}(6) \\
(6925 \pm 2721\end{array}$ \\
\hline
\end{tabular}

Values are means \pm SEM with the number of animals in parenthesis.

study. It can be seen that the obese animals weigh considerably more than their controls, and that the excess weight is completely accounted for by the excess lipid content of the animals. The plasma insulin and pancreatic insulin content are greatly elevated in the obese mice.

Fig. 1 presents the plasma glucose levels and the specific activity of the plasma glucose of lean and obese mice during the experimental period following ${ }^{14} \mathrm{C}$ glucose injection. Although the obese mice have a higher plasma glucose, which in turn is responsible for synthesis between the two types of mice in the skin or remaining carcass and only a small difference in the intestine (Fig. 3). Although only small, and rather variable amounts of labelled, newly synthesised lipids were recovered from the plasma, there was a tendency for the obese to have greater amounts than the lean. In Table 2 it can be seen that saponifiable fatty acids accounted for a much higher proportion of the total radioactivity in lipids in the liver of obese animals than in the lean. This was also true in both epididymal and subcutaneous adipose tissue. 
It seemed important to attempt to decide whether the large incorporation of label into adipose tissue lipids in the obese animals represented synthesis actually in adipose tissue or uptake from the blood of lipids synthesised in the liver. Experiments were therefore carried out in which the liver was excluded from the circulation in some animals by tying ligatures

LIVER

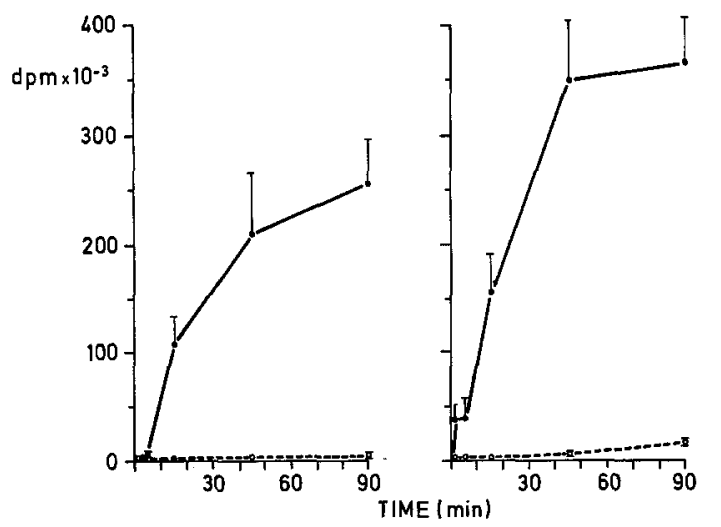

Fig. 2. Incorporation of radioactivity into saponifiable fatty acids of liver and adipose tissue of lean and $o b / o b$ mice following an intravenous dose of ${ }^{14} \mathrm{C}$ glucose. Mice anaesthetised with Nembutal were injected in a tail vein with a small amount of ${ }^{14} \mathrm{C}$ glucose $(5 \mu \mathrm{C})$. At various times later they were killed and tissues analysed for radioactivity in saponifiable fatty acids. Each value is mean \pm SEM of 6 animals. Lean mice $0 \cdots 0$ ob/ob mice

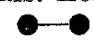

Table 2. Incorporation of ${ }^{14} C$ glucose into lipid fractions of several tissues of lean and $o b / o b$ mice

Percentage of total lipid radioactivity found as:

\begin{tabular}{|c|c|c|c|c|}
\hline Tissue & Animal & $\begin{array}{l}\text { Non } \\
\text { saponifiable } \\
\text { lipids }\end{array}$ & Glycerol & $\begin{array}{l}\text { Glyceride } \\
\text { fatty } \\
\text { acid }\end{array}$ \\
\hline Liver & $\begin{array}{l}\text { lean } \\
\text { obese }\end{array}$ & $\begin{array}{l}0.4 \pm 0.1 \\
0.7 \pm 0.1\end{array}$ & $\begin{array}{l}96 \pm 9 \\
58 \pm 6\end{array}$ & $\begin{array}{r}4 \pm 1 \\
42 \pm 6\end{array}$ \\
\hline $\begin{array}{l}\text { Epididymal } \\
\text { adipose tissue }\end{array}$ & $\begin{array}{l}\text { lean } \\
\text { obese }\end{array}$ & $\begin{array}{l}0.4 \pm 0.1 \\
0.9 \pm 0.2\end{array}$ & $\begin{array}{l}89 \pm 2 \\
49 \pm 7\end{array}$ & $\begin{array}{l}11 \pm 2 \\
50 \pm 7\end{array}$ \\
\hline $\begin{array}{l}\text { Subcutaneous } \\
\text { adipose tissue }\end{array}$ & $\begin{array}{l}\text { lean } \\
\text { obese }\end{array}$ & $\begin{array}{l}0.2 \pm 0.1 \\
0.5 \pm 0.1\end{array}$ & $\begin{array}{l}91 \pm 1 \\
67 \pm 13\end{array}$ & $\begin{array}{r}9 \pm 1 \\
32 \pm 4\end{array}$ \\
\hline Intestine & $\begin{array}{l}\text { lean } \\
\text { obese }\end{array}$ & $\begin{array}{l}3.4 \pm 1.6 \\
3.2 \pm 0.3\end{array}$ & $\begin{array}{l}77 \pm 7 \\
65 \pm 1\end{array}$ & $\begin{array}{l}20 \pm 3 \\
31 \pm 2\end{array}$ \\
\hline Skin & $\begin{array}{l}\text { lean } \\
\text { obese }\end{array}$ & $\begin{array}{r}12.6 \pm 1.6 \\
6.0 \pm 2.0\end{array}$ & $\begin{array}{ll}33 \pm 5 \\
66 \pm 5\end{array}$ & $\begin{array}{l}54 \div 2 \\
28 \pm 5\end{array}$ \\
\hline Carcass & $\begin{array}{l}\text { lean } \\
\text { obese }\end{array}$ & $\begin{array}{l}4.4 \pm 0.5 \\
4.6 \pm 2.0\end{array}$ & $\begin{array}{l}56 \pm 6 \\
59 \pm 5\end{array}$ & $\begin{array}{l}40 \pm 6 \\
37 \pm 6\end{array}$ \\
\hline
\end{tabular}

Anaesthetised mice were injected $\mathrm{i}-\mathrm{v}$ with a trace amount of ${ }^{14} \mathrm{C}$ glucose and $90 \mathrm{~min}$ later various tissues were removed, the lipids extracted and treated as described in methods. The amount of radioactivity detected in each lipid fraction is expressed as a percentage of the total radioactivity in lipids in tissue. Each value is the mean from 6 animals.

around the hepatic artery and portal vein, a modification of the procedure described by Russell [4]. Such animals had virtually no label recovered from their liver lipids $90 \mathrm{~min}$ after the injection of trace amounts of ${ }^{14} \mathrm{C}$ glucose, but had substantial radioactivity present in the lipids of adipose tissue (Fig. 4). This suggests that in both lean and obese animals the counts

INTESTINE
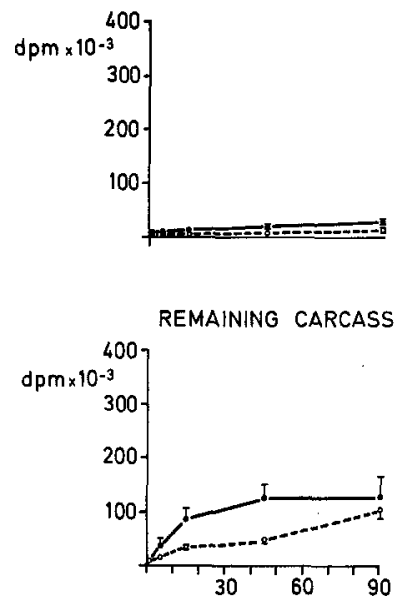

Fig. 3. Incorporation of radioactivity into saponifiable fatty acids of various tissues and plasma of lean and $o b / o b$ mice following an intravenous dose of ${ }^{14} \mathrm{C}$ glucose. Lean mice 0 -..- 0 ob/ob mice - Each point is the mean \pm SEM of 6 animals. Experimental procedure as described in Fig. 2

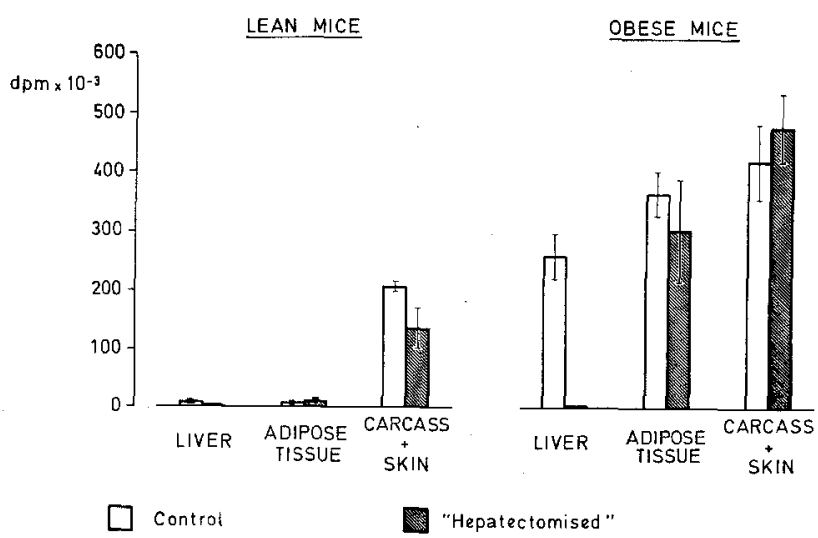

Fig. 4. Incorporation of radioactivity into saponifiable fatty acids of various tissues following an intravenous dose of ${ }^{14} \mathrm{C}$ glucose in "hepatectomised" $o b / o b$ and lean mice. Anaesthetised mice had ligatures placed around their hepatic artery and portal vein and were subsequently given $5 \mu \mathrm{C}$ of ${ }^{14} \mathrm{C}$ glucose intravenously. After $90 \mathrm{~min}$ the incorporation of label into the glyceride fatty acids of several tissues was measured as described in the methods section. The bar labelled carcass and skin includes the radioactivity in adipose tissue adhering to these samples 
recovered in the lipids of adipose tissue represented mainly lipids synthesised in situ rather than lipids synthesised in the liver, transported in the blood and subsequently taken up by adipose tissue.

The coexistence of a high level of plasma insulin with an elevated glucose in the obese mice indicates that these animals have a resistance to the action of insulin. This resistance has been demonstrated in vivo by the meagre fall in blood sugar following an intraperitoneal dose of insulin [10] and it has also been shown, in vivo, to occur both in diaphragm muscle, and in adipose tissue [11]. levels. As shown in Table 3, the insulin caused a small but significant stimulation in the incorporation of label into liver saponifiable lipids in the lean mice, but caused a great increase in the incorporation into adipose tissue lipids. This was particularly prominent in the case of subcutaneous adipose tissue which appears to be more insulin sensitive than epididymal adipose tissue in these mice. Because the two types of adipose tissue responded differently to insulin, it was not possible to estimate the incorporation of radioactivity into total adipose tissue of the lean animals using the same calculation as had been used in the non

Table 3. Effect of insulin, streptozotocin diabetes and anti-insulin serum injection, on the incorporation of ${ }^{14} C$ glucose into saponifiable fatty acids in vivo

\begin{tabular}{|c|c|c|c|c|c|}
\hline \multirow[t]{3}{*}{ Tissue } & \multirow[t]{3}{*}{ Animal } & \multicolumn{4}{|l|}{ Treatment } \\
\hline & & Controla & Insulin & Streptozotocin & $\begin{array}{l}\text { Anti-insulin } \\
\text { serum }\end{array}$ \\
\hline & & \multicolumn{4}{|c|}{ dpm. incorporated $\times 10^{-3}$} \\
\hline Liver & $\begin{array}{l}\text { lean } \\
\text { obese }\end{array}$ & $\begin{array}{r}4.5 \pm 1.2 \\
177.8 \pm 19.7\end{array}$ & $\begin{array}{r}10.5 \pm 1.5 \\
105.5 \pm 18.6\end{array}$ & $\begin{array}{c}0.3 \pm 0.05 \\
55.0 \pm 22.8\end{array}$ & $\begin{array}{r}1.1 \pm 0.4 \\
16.9 \pm 8.7\end{array}$ \\
\hline $\begin{array}{l}\text { Epididymal } \\
\text { adipose tissue }\end{array}$ & $\begin{array}{l}\text { lean } \\
\text { obese }\end{array}$ & $\begin{array}{r}2.6 \pm 0.9 \\
19.8 \pm 3.4\end{array}$ & $\begin{array}{l}24.0 \pm 5.9 \\
17.6 \pm 4.7\end{array}$ & $\begin{array}{ll}0.5 \pm & 0.1 \\
0.7 \pm & 0.1\end{array}$ & $\begin{array}{l}0.6 \pm 0.1 \\
2.5 \pm 0.6\end{array}$ \\
\hline $\begin{array}{l}\text { Subcutaneous } \\
\text { adipose tissue }\end{array}$ & $\begin{array}{l}\text { lean } \\
\text { obese }\end{array}$ & $\begin{array}{r}2.2 \pm 0.3 \\
13.1 \pm 2.2\end{array}$ & $\begin{array}{l}112.7 \pm 23 \\
7.9 \pm 1.3\end{array}$ & $\begin{array}{l}1.1 \pm 0.5 \\
0.7 \pm 0.2\end{array}$ & $\begin{array}{l}1.8 \pm 0.2 \\
1.2 \pm 0.4\end{array}$ \\
\hline $\begin{array}{l}\text { Total } \\
\text { adipose tissue }\end{array}$ & $\begin{array}{l}\text { lean } \\
\text { obese }\end{array}$ & $\begin{array}{r}5.4 \pm 1.0 \\
343.6 \pm 36.1\end{array}$ & $\begin{array}{l}254.5 \pm 29.9^{\mathrm{d}} \\
315.6 \pm 34.2\end{array}$ & $\begin{array}{r}0.9 \pm 0.3 \\
12.9 \pm 3.5\end{array}$ & $35.4 \pm 9.8$ \\
\hline Intestine & $\begin{array}{l}\text { lean } \\
\text { obese }\end{array}$ & $\begin{array}{l}15.5 \pm 4.0 \\
29.2 \pm 2.3\end{array}$ & $\begin{array}{l}26.6 \pm 2.6 \\
22.1 \pm 3.4\end{array}$ & $\begin{array}{ll}1.8 \pm & 0.2 \\
7.7 \pm & 1.4\end{array}$ & $\begin{array}{l}2.2 \pm 0.4 \\
5.0 \pm 1.2\end{array}$ \\
\hline Skin & $\begin{array}{l}\text { lean } \\
\text { obese }\end{array}$ & $\begin{array}{l}50.0 \pm 5.8 \\
42.1 \pm 8.5\end{array}$ & $\begin{array}{l}25.5 \pm 6.9 \\
48.9 \pm 5.9\end{array}$ & $\begin{array}{r}0.8 \pm 0.4 \\
16.4 \pm 4.1\end{array}$ & $\begin{array}{l}22.2 \pm 4.8 \\
13.9 \pm 2.2\end{array}$ \\
\hline Carcass & $\begin{array}{l}\text { lean } \\
\text { obese }\end{array}$ & $\begin{array}{r}96.6 \pm 11.4 \\
133.2 \pm 33.6\end{array}$ & $\begin{array}{l}289.6 \pm 24.0^{\mathrm{c}} \\
150.1 \pm 10.0\end{array}$ & $\begin{array}{r}2.2 \pm 1.0 \\
28.3 \pm 7.5\end{array}$ & $\begin{array}{l}23.4 \pm 5.2 \mathrm{c} \\
36.2 \pm 7.7\end{array}$ \\
\hline $\begin{array}{l}\text { Plasma glucose } \\
\mathrm{mg} / 100 \mathrm{ml}\end{array}$ & $\begin{array}{l}\text { lean } \\
\text { obese }\end{array}$ & $\begin{array}{l}138 \pm 7 \\
221 \pm 20\end{array}$ & $\begin{array}{r}48 \pm 10 \\
125 \pm 7\end{array}$ & $\begin{array}{l}661 \pm 33 \\
459 \pm 43\end{array}$ & $\begin{array}{l}219 \pm 14 \\
663 \pm 68\end{array}$ \\
\hline $\begin{array}{l}\text { Glucose specific } \\
\text { activity } \mathrm{dpm} / \mu \mathrm{g}\end{array}$ & $\begin{array}{l}\text { lean } \\
\text { obese }\end{array}$ & $\begin{array}{l}285 \pm 31 \\
117 \pm 18\end{array}$ & $\begin{array}{l}59 \pm 15 \\
56 \pm 5\end{array}$ & $\begin{array}{r}81 \pm 9 \\
115 \\
\pm 20\end{array}$ & $\begin{array}{r}245 \pm 31 \\
69 \pm 7\end{array}$ \\
\hline
\end{tabular}

a The controls for all the groups did not differ and have been pooled.

b Expressed as specific activity of extracted lipid in $\mathrm{dpm} / \mathrm{g}$ lipid.

c Value includes contaminating adipose tissue (see text)

a Estimated as described in the text.

Either normal mice, insulin treated mice, streptozotocin diabetic mice, or mice treated with anti-insulin serum were given $5 \mu \mathrm{C}$ of $\mathrm{U}^{-14} \mathrm{C}$ glucose into a tail vein and the incorporation of label into saponifiable fatty acids measured $90 \mathrm{~min}$ later, as described in the methods section. Values are means \pm SEM of 6 animals, except for the control group which includes 12 animals.

In view of this we have directly tested the effect of administered insulin on lipogenesis in lean and obese mice. Insulin was given intravenously with the ${ }^{14} \mathrm{C}$ glucose and in two further injections, 30 and $60 \mathrm{~min}$ later. The obese mice received a larger dose of insulin calculated to raise their plasma IRI levels at least as many fold as had the dose given to the lean mice. In fact the insulin levels of the lean mice, measured 10 min after the first injection of insulin, had risen 6 fold above the normal value and, in the case of obese mice, the dose used caused a 10 fold rise in peripheral insulin insulin treated animals. Instead, on the assumption that insulin affects the incorporation of radioactivity into adipose tissue to a much greater extent than into other tissues, a figure has been derived by subtracting the total radioactivity found in the whole animal, excluding the liver, of non insulin treated mice, from the corresponding figure for insulin treated mice. Similarly, since it is not known whether the adipose tissue that contaminates the remaining carcass behaves like epididymal adipose tissue, or like subcutaneous adipose tissue, no value could be assigned to the in- 
corporation into the carcass. In Table 3 the value corresponding to the incorporation into the carcass, including its contaminating adipose tissue is presented. This figure is clearly larger than the value of carcass plus total adipose tissue in non insulin-stimulated mice and it suggests that much of the contaminating adipose tissue is responding very well to the insulin. Under the influence of insulin, the total incorporation into the lean mice (excluding the incorporation into the liver) approaches the incorporation seen in the obese mice not stimulated with insulin $\left(4.22 \times 10^{5} \mathrm{dpm} / \mathrm{lean}\right.$ animal, $5.48 \times 10^{5} \mathrm{dpm} /$ obese animal). The intestine of non treated $227 \pm 7 \mathrm{mg} / \mathrm{g}$ liver, obese treated $60 \pm 3$ $\mathrm{mg} / \mathrm{g}$ liver). As can be seen from Table 3, lipogenesis was strongly depressed in all tissues of streptozotocin treated lean mice. The same was true of streptozotocin treated obese mice. This decrease was particularly marked in the case of adipose tissue and somewhat less marked in the case of the liver. The incorporation of label into saponifiable lipids was decreased by streptozotocin treatment to a greater extent than incorporation into total lipids, in both liver and adipose tissue. Saponifiable fatty acids accounted for $29 \%$ of the total in the liver and $9 \%$ and $7 \%$ in epididymal and sub-

\begin{tabular}{|c|c|c|c|c|c|c|}
\hline & $\begin{array}{l}\text { Age in } \\
\text { weoks }\end{array}$ & $\begin{array}{l}\text { Weight } \\
\mathrm{g}\end{array}$ & $\begin{array}{l}\text { Total body } \\
\text { lipid } \\
\mathrm{g}\end{array}$ & $\begin{array}{l}\text { Percentage of } \\
\text { body weight } \\
\text { as lipid }\end{array}$ & $\begin{array}{l}\text { Plasma } \\
\text { IRI } \\
\mathrm{ng} / \mathrm{ml}\end{array}$ & $\begin{array}{l}\text { Pancreatio } \\
\text { IRI content } \\
\text { ng/pancreas }\end{array}$ \\
\hline lean & $9-12$ & $22.2 \pm 0.5$ & $1.1 \pm 0.2$ & 5.0 & $0.73 \pm 0.03$ & $231 \pm 46$ \\
\hline obese & $9-12$ & $41.4 \pm 1.8$ & $17.1 \pm 1.0$ & 41.3 & $3.41 \pm 1.1$ & $1663 \pm 874$ \\
\hline
\end{tabular}

Values are means \pm SEM of 6 animals.

the lean animals showed a small response to insulin consistent with a minor contamination with adipose tissue. The skin, however, contained less labelled lipid than in controls, suggesting that it is not responsive to insulin and that the decreased incorporation simply reflects the decreased specific activity of precursor glucose under the influence of insulin. This decreased specific activity at the end of the experiment is shown in Table 3 , as is the lower plasma glucose at the end of the experiment.

In contrast to the case in the lean animals, insulin did not stimulate the incorporation of radioactivity into lipids of either liver or adipose tissue of obese animals. In fact there was a decrease in the incorporation into liver lipids, possibly due to the diversion of glucose to other fates in other tissues. It is clear that the insulin had had some metabolic effect in the obese mice, since both the glucose level and glucose specific radioactivity were decreased at the end of the experiment.

Since the lean mice responded to administered insulin with an increased lipogenesis, while the obese mice did not, it is possible that lipogenesis in the obese mice was maximally stimulated, in the absence of exogenous, insulin, by the high endogenous insulin level. If this were true, then decreasing the insulin level should at least partially correct the increased lipogenesis of the $o b / o b$ mouse. Both lean and obese mice treated with streptozotocin had lower serum insulin levels than non treated mice (Table 4) and were glucosuric as judged by daily tests with Clinistix. Pancreatic insulin contents were also reduced in both the lean and obese. It was also noted that the liver lipid content of streptozotocin treated obese mice fell to a value close to that of lean mice (lean-non treated $53 \pm 1 \mathrm{mg} / \mathrm{g}$ liver, lean treated $51 \pm 2 \mathrm{mg} / \mathrm{g}$ liver, obese- cutaneous adipose tissue respectively (cf Table 2). It is clear therefore that the decreased insulin levels caused by streptozotocin treatment were associated with at least a partial reversal of the abnormally high lipogenesis in these two tissues.

Another way to decrease circulating insulin levels is by the injection of anti-insulin serum [12]. The success of this procedure can be seen by the increased plasma glucose present at the end of the experiment (Table 3). Lean mice treated with anti-insulin serum had only a moderate decrease in the accumulation of radioactivity in saponifiable lipids of all tissues studied. The small magnitude of this change suggests that lipogenesis in the lean mice was not significantly stimulated by endogenous insulin. This is consistent with the low basal incorporation seen in adipose tissue and the large response to exogenous insulin.

Obese mice treated with anti-insulin serum had an elevated plasma glucose at the end of the experiment. However the decreases seen in label incorporated into saponifiable lipids of liver and adipose tissue appears too large to be due solely to the decrease in glucose specific activity brought about by the hyperglycaemia. The decreased incorporation was particularly marked in the case of adipose tissue. As in the streptozotocin treated mice, not only was the absolute incorporation decreased by anti-insulin serum, but the percentage of total label that was saponifiable fatty acid was also decreased.

\section{Discussion}

Interpretation of experiments of the kind done in this work is difficult for several reasons. The radioactivity recovered from a tissue does not bear a constant relationship to the rate of lipogenesis in that 
tissue during the experiment unless two conditions are fulfilled. Firstly, the specific activity of the precursor for lipogenesis, namely plasma glucose, must be comparable under the various conditions studied. Secondly, dilution of radioactivity by other endogenous lipid precursors within the tissue should also be comparable. In these experiments we have measured the specific radioactivity of the glucose present at the end of our experiments, and also the plasma glucose level. It is thus possible to make some allowance for variations in the specific activity of the precursor glucose. The second condition is very difficult to control, and no attempt has been made to do so.

A further complication in interpretation is that radioactive carbon will be incorporated not only into de novo synthesised fatty acids but also into preexisting fatty acids that have simply undergone chain elongation. Consequently, a tissue with an active fatty acid elongating system will have a high incorporation, giving the impression of a tissue actively synthesising lipids.

Because of these difficulties it is not reasonable to attempt to interpret small changes in these experiments. However, large differences are very likely to reflect real phenomena.

The largest difference observed in these studies was between the incorporation of label into saponifiable lipids in the liver and in adipose tissue of obese, compared with lean mice. This finding was the more remarkable since the differences between these mice in the lipogenesis of other tissues was rather small. It appears that the abnormally high rates of lipogenesis found in the obese animals are mainly expressed in the liver and adipose tissue, tissues which are known to be the major sites of fatty acid synthesis in higher animals. This conclusion is reinforced by the fact that the lower glucose specific radioactivity observed in the obese mice would tend to minimize such a difference.

The experiments in which the liver was excluded from the circulation indicate that under circumstances when the liver accumulates almost no radioactivity in lipids, adipose tissue can continue to incorporate precursor into lipids to a substantial extent. This finding is particularly clear in the obese mice and suggests that both the liver and adipose tissue of the obese mice have an increased lipogenic capacity.

The demonstration that in lean mice also, exclusion of the liver allows lipid synthesis to continue in adipose tissue and in the carcass, shows that these tissues possess the eapacity to synthesise lipids in situ. This finding, along with the low incorporation found in the liver of control mice, and the high incorporation into adipose tissue under the influence of insulin, suggests that the liver is not a major site of lipid synthesis, in the lean mice, in confirmation of previous work with albino mice [13].

These results, obtained in vivo, are in general agreement with earlier reports on the lipogenic capacity of adipose tissue of $o b / a b$ mice in vitro. Thus it has been demonstrated that, although adipose tissue from these mice has a decreased capacity to convert glucose to lipid in vitro, when expressed on a tissue nitrogen basis, they have an increased lipogenic capacity from several different precursors expressed on a per fat pad basis $[14,15]$. This increase would be even more marked on a per animal basis as used in the present work. This problem has been recently discussed in the literature [16].

The rather remarkable response of adipose tissue of lean mice to exogenous insulin, which brought total lipogenesis in the lean animals towards that in the obese, also raised the possibility that the obese adipose tissue has such a high incorporation because of the high endogenous insulin in these animals. This postulate is also in accord with the lack of insulin sensitivity of obese adipose tissue in vivo, if it is assumed that the high endogenous insulin has already almost maximally stimulated lipogenesis in these mice. Whether this is true or not is not definitely established, but it is clear that the exogenous insulin did increase the disposal of glucose in the obese mice, since both the absolute glucose level and the glucose specific activity decreased following insulin treatment. Indeed, if it is reasonable to postulate that this decreased glucose specific activity can explain the inhibitory effect of insulin on lipid synthesis in obese livers, then it is clear that the absence of a response in adipose tissue could equally denote an actual small increase in lipid synthesis, so that accumulation of label was unaltered despite the lower specific activity of glucose.

In interpreting these experiments, it should be remembered that, even in the obese mice, incorporation into saponifiable lipids is not a major fate of glucose, and at most, in the obese, can account for $10 \%$ of glucose disappearing from the blood.

The possibility that the high incorporation in obese animals is a response to the high insulin levels, receives some support from the experiments with streptozotocin and anti-insulin serum. In both these cases, glucose disposal was decreased, as shown by the increased plasma glucose and glucose specific activity at the end of the experiment. Lipogenesis was decreased in all tissues studied, but the decrease was most pronounced in the case of adipose tissue. It was also evident in the liver, but not as marked. The fact that lipogenesis did not return to the levels seen in control mice may have been due to the fact that these mice still had elevated plasma insulin levels (Table 4).

It is difficult to establish the relevance of the present findings to the development of obesity in the $o b / o b$ mouse. It would appear that the increased lipogenesis seen at the age of $9-12$ weeks can be to a large extent explained on the basis of a raised insulin level and elevated serum glucose. However, because even in the streptozotocin diabetic and anti-insulin treated $o b / o b$ mice incorporation of label was still higher than in controls, it is evident that the increased lipogenesis has been only partially reversed. While it 
is, therefore, not possible to conclude that a high insulin level is the only cause of the increased incorporation seen in the obese mice, it seems likely that it can provide an explanation for a substantial part of the abnormality. It seems possible that the genetic lesion in these animals causes, by some obscure mechanism, an elevation of the plasma insulin, which in turn induces increased fat deposition and obesity. It is also possible that at a younger age, during the development of obesity, there is a primary abnormality in peripheral tissues which causes hyperinsulinaemia and thus fat deposition, and that this abnormality is obscured in the present studies by the secondary changes in response to hyperinsulinaemia. Investigation of these animals at the stage when they first display metabolic abnormalities may be a useful approach to this problem.

Acknowledgments. The authors thank Dr. M.D. Siperstein for his useful suggestions during the preparation of this manuscript. They are greatly indebted to Miss Martha Bezemer for her dedicated and excellent technical assistance. The artistic contribution of Mr. M. Kessi in the making of the figures and the care of Mr. J.J. Goy in keeping the Animal House is also greatfuly acknowledged. E. G.L. a.cknowledges the financial assistance of the New Zealand Medical Research Council.

\section{References}

1. Shigetta, Y., Shroeve, W.W.: Fatty acid synthesis from glucose-1 ${ }^{3} \mathrm{H}$ and glucose-1 ${ }^{14} \mathrm{C}$ in obese hyperglycaemic mice. Amer. J. Physiol, 206, 1085-1090 (1964)

2. Bates, M.W., Zomzely, C., Mayer, J.: Fat metabolism in three forms of experimental obesity. IV. Instantaneous rates of lipogenesis in vivo. Amer. J. Physiol. $181,187-190(1955)$

3. Jansen, G.R., Zanetti, M.E., Hutchison, C.F.: Studies on lipogenesis in vivo. Fatty acid and cholesterol synthesis in hyperglycaemic-obese mice. Biochem. J. 102, 870-877 (1967)

4. Winand, J.: Aspects qualitatifs et quantitatifs du métabolisme lipidique de la souris normale et de la souris congénitalement obèse. Bruxelles: Editions Arscia S.A. 1970

5. Folch, J., Lees, M., Sloane-Stanley. G.H.: A simple method for the isolation and purification of total lipids from animal tissues. J. biol. Chem. 226, 497$509(1957)$
6. Exton, J.H., Park, C.R.: Control of gluconeogenesis in the liver. 1. General features of gluconeogenesis in the perfused livers of rats. J. biol. Chem. 242, 2622$2636(1967)$

7. Herbert, V., Lau, K.S., Gottlieb, G.W., Bleicher, J.J.: Coated charcoal immunoassay of insulin. J. clin. Endocr. 25, 1375-1384 (1965)

8. Russell, J.A.: The anterior pituitary in the carbohydrate metabolism of the oviscerated rat. Amer. J. Physiol. 136, 95-104 (1942)

9. Stauffacher, W., Lambert, A. E., Vecchio, D., Renold, A.E.: Measurement of insulin activities in pancreas and serum of mice with spontaneous ("obese and New Zealand obese") and induced (goldthioglucose) obesity and hyperglycaemia, with considerations on the pathogenesis of the spontaneous syndrome. Diabetologia 3, 230-237 (1967)

10. Mahler, R.J., Szabo, O.: Amelioration of insulin resistance in obese mice. Amer. J. Physiol. 221, 980 $983(1971)$

11. Stauffacher, W., Renold, A.E.: Effect of insulin in vivo on diaphragm and adipose tissue of obese mice. Amer. J. Physiol. 216, 98-105 (1969)

12. Barling, P., Beloff-Chain, A.: Studies on the administration of glucagon and insulin antibodies to rats. Horm. Metab. Res. 5, 154-159 (1973)

13. Favarger, P., Gerlach, J.: Recherches sur la synthèse des graisses à partir d'acetate ou de glucose. II. Les rôles respectifs du foie, du tissu adipeux et de certains autres tissus dans la lipogenèse chez la souris. Helv. physiol. pharmacol. Acta 13, 96-105 (1955)

14. Christophe, J., Jeanrenaud, B., Mayer, J., Renold, A.E.: Metabolism in vitro of adipose tissue in obesehyperglycaemic and goldthioglucose-treated mice. I. Metabolism of glucose J. biol. Chem. 236, 642-647 (1961)

15. Christophe, J., Jeanrenaud, B., Mayer, J., Renold, A. E.: Metabolism in vitro of adipose tissue in obesehyperglycaemic and goldthioglucose-treated mice. II Metabolism of pyruvate and acetate. J. biol. Chem. 236, $648-652(1961)$

16. Abraham, R.R.: Some cellular characteristics of the epididymal adipose tissue in lean and obese-hyperglycaemic mice. Diabetologia, 9, 303-306 (1973)

Prof. B. Jeanrenaud

Laboratoires de Recherches Médicales

Université de Genève

Avenue do la Roseraie 64

CH-1211 Genève 4

Switzerland 